\title{
The Aesthetics of Exhibitionism: Oscar Wilde as a Public Aesthete
}

\author{
Yang Yu \\ English Department, School of Foreign Languages and Literature, Beijing Normal University, Beijing, China \\ Email address: \\ celavieglove@126.com \\ To cite this article: \\ Yang Yu. The Aesthetics of Exhibitionism: Oscar Wilde as a Public Aesthete. English Language, Literature \& Culture. \\ Vol. 5, No. 1, 2020, pp. 36-44. doi: 10.11648/j.ellc.20200501.14
}

Received: January 24, 2020; Accepted: February 14, 2020; Published: February 25, 2020

\begin{abstract}
Oscar Wilde develops a unique way of critical arguments in which the critical discourse carries a special exhibition effect. Despite his condemnation of the contemporary tendency that literature appeals more to the eye, this visuality in language reveals his desire for self-exhibition in the public domain. Therefore, Wilde distinguishes himself from other intellectuals of his time by providing a sensation for the pleasure of eyes and by offering a new visual pattern for the intellectual attraction to the public. The present paper attempts to demonstrate that a sort of exhibitionism functions as a foundational element in Wilde's literary creation. His critical essays, as represented by "The Critic as Artist," are characterized by a conspicuous exhibition of classical knowledge and aesthetic temperament. In his advocacy of "art for art's sake," artistic uniqueness is interrelated with the widespread pursuit of visual stimulus and display of difference among the reading public of the late Victorian period. Thus, it is impossible to have a comprehensive understanding of Wilde's literary achievement and aesthetic sensibilities without serious consideration of his publicity-seeking self-exhibition. In this sense, the paper tends to show that Wilde's aestheticism is, in essence, the aesthetics of exhibitionism. It regards superficial quality as the high standard of wit, style the very condition of art, and appearance the real nature of life.
\end{abstract}

Keywords: Exhibitionism, Public Aesthete, Style, Sensation

\section{Introduction}

The recent Wildean studies have shown more and more interests in Wilde's interconnection with the public. Firstly, Wilde's three trials with Lord Alfred Douglas's father are studied from various aspects. Dale Barleben traces Wilde's literary epigrams with its relation to the legal development of the time [1]. Tara Penry exposes the dubious justice of the Victorian public towards Wilde's trials by studying American author Bret Harte's story "Bulger's Reputation" which was written in London shortly after Wilde's conviction [2]. Secondly, Wilde's queer identity is further explored with new perspectives. Abigail Joseph points out the literary connection between Wilde's experiences as an editor in The Woman's World and the publication of The Picture of Dorian Gray, the "foundational texts of gay style" [3]. Nick Freeman studies Wilde's influence in Victorian London's homosexual subculture [4]. Thirdly, Wilde's influences on later generations are explored, which are usually related to the trials or Wilde's queer identity. Freeman does research in this aspect, and James Patrick Wilper argues that Wilde "became for decades afterward the only signifier available to many to name same-sex acts" [5]. As these studies show, to examine Wilde through a contextualized historical perspective has become an important approach. The present study attempts to focus on the period of 1883 to 1891 to explore the forming years for Wilde to become a public aesthete. There is no denying that long before Oscar Wilde achieved his great success with his social comedies in the theatrical world of London in the 1890s, he had already established himself as a public aesthete. From the publication of Poems in 1881 to the opening performance of Lady Windermere's Fan in 1893, the process lasted over one decade. During those years, the aestheticism that Wilde had taken over from John Ruskin and Walter Pater in his Oxford years got fully entangled with the philistine world. In the early $1880 \mathrm{~s}$, aestheticism became the target of several contemporary satirists. Wilde's American tour in 1882 was, from the very start, involved in the cultural industry of advertisement and marketing strategies. For the rest of the decade, Wilde worked mainly as a professional journalist for 
many newspapers. It was through these experiences that the Wildean aestheticism acquired its own character, which eventually led up to his theatrical success. It was also out of the anxiety about these influences that Wilde published his most famous collection of critical essays Intentions in 1891, the same year when his most controversial novel The Picture of Dorian Gray appeared in book form. This paper aims to show that Wilde's commitment to aestheticism was a process towards the aesthetics of conspicuous exhibition, whereby the personal aesthetic experience gradually mingled with the public celebration of vulgarity and sensation. Wilde actually inserted his criticism into an account of visual display that had become popular in this market. Against this cultural background, the aesthetic critic developed a sort of stylistic criticism focusing on the construction of artistic personality, the creation of sensational effect, and the self-centered display of style and learning.

\section{The Aesthetic Critic and "The Survival of the Vulgarest"}

Although its slogan "art for art's sake" calls for a release from practical need and purpose, British aestheticism, as exemplified by Oscar Wilde in particular, is, in essence, not alien from social life. For Wilde, aesthetic criticism never loses its identity as a public discourse. Wilde claims in one of his American lectures: "The true critic addresses not the artist but the public only" [6]. Therefore, it is not wise to overlook the connection between Wilde's aesthetic criticism and the late-Victorian reading public. If the intellectual critic (such as Matthew Arnold), "by its display of careful extrication from controversy" [7], cloaks its public ambition in invisibility, the aesthetic critic, on the contrary, tries every possible means to become a visible focus in public. The aesthetic quest for public self-exhibition opens up new ways of self-articulation, through which Wilde gets himself and his aestheticism involved in the popular cultural market of "the survival of the vulgarest" [8].

As a critic unequivocally addressing to the social world, Wilde was well aware of the changes that were occurring to his time. He realized that the traditional cultural critic of a prudent reasoning mind did not appeal much to the mass; instead, they were now avaricious of a visual presentation. He wrote in "The Critic as Artist", "there has been a tendency in literature to appeal more and more to the eye and less and less to the ear" [8]. Wilde's perceptive observation on the increase of lower-class readers and their mania for visual stimulus indicated the general trend in the late-Victorian reading market. The number of readers in England and Wales in 1851 was about 11,000,000, but in 1891 when Wilde's Intentions was published, it nearly reached 29,000,000 [9]. The great expansion of the reading circle was mainly caused by the formation of the working-class readers. With earnest attention to the economic interests and political rights of their own, the working-class people developed a habit of self-cultivation. They confidently looked forward to the realization of a new cultural harmony in which a genuine social community could be forged on the basis of self-improvement. Thus, an overwhelming majority of the laboring people were enthusiastic about acquiring various kinds of knowledge. Nevertheless, due to the limitations of leisure time and intellectual capacity, most of the masses could only read some popular newspaper articles and simple political pamphlets. A sort of imbalance emerged out of this potential conflict between a keen political consciousness and the lack of intellectual perception. In as early as 1855 , Walter Bagehot, one of the most influential journalists of the mid-Victorian period, had already noted the trend: "It is of no use addressing them with the forms of science, or the rigor of accuracy, or the tedium of exhaustive discussion. The multitudes are impatient of system, desirous of brevity, puzzled by formality" [10]. Bagehot's description provided a suggestive epitome of the cultural market where "this appeal to the many" heralded the ultimate failure of cultural elites for a canonical position in the society. In this reader-oriented cultural market, the critical discourse of the intellectuals could no longer take the priority in deciding what was acceptable. The reading public had an unappeasable thirst for sensual stimulus. Thus, newspapers and periodicals of the period emotionally bullied the readers with various sensational events. This intentional effort to please the public formed the general line of orientation throughout the rest of the nineteenth century. The decade of the 1880s indeed witnessed a rapid development of the journalistic profession with several great newspaper personalities appearing on the stage of British journalism. One of them was William Thomas Stead. Holding the editor's chair of Pall Mall Gazette, Stead claimed to "have revolutionized English journalism" and made "journalism a living thing, palpitating with actuality, in touch with life at all points" [11]. With Stead and his contemporary journalists' celebration of connecting journalistic reports with daily life, certain stylistic changes happened to the journalistic writing in the last two decades of the century. Ed Cohen notices that the new style, as epitomized by Stead's editorship of Pall Mall Gazette, sought to "establish an emotional relationship to the audience by drawing upon new personalized narration, vivid language, evocative detail, and most important of all, sensational subjects" [12].

It is noteworthy that Oscar Wilde's first popular press article, "Mr. Oscar Wilde on Woman's Dress", was just received by Stead and published in Pall Mall Gazette on 14, October 1884 . From 1884 to 1889 , nearly the same period when Stead was the editor of Pall Mall Gazette (1883-1889), Wilde produced no less than ninety essays for Pall Mall Gazette, surpassing in number the articles he published in other periodicals, either literary or non-literary. Many of the essays were concerned with daily topics. "More Radical Ideas upon Dress Reform" continued the discussion about the contemporary dress that had been discussed in "Mr. Oscar Wilde on Woman's Dress". "Dinners and Dishes" picked up the topic of cookery. "A Handbook to Marriage" was a book review on the popular book How to be Happy though Married: Being a Handbook to Marriage. During the same period, 
Wilde also contributed to several other newspapers, as well as having worked as the editor of The Woman's World for about two years. According to Anya Clayworth, up to 1898 when his final article was published in The Daily Chronicle, Wilde had written for over fifty periodicals [13]. In "The Critic as Artist," Wilde wrote, "As for modern journalism, it is not my business to defend it. It justifies its own existence by the great Darwinian principle of the survival of the vulgarest. I have merely to do with literature" [8]. With a subtle adaptation of the Darwinian term "the survival of the fittest," Wilde ridiculed the vulgar nature of journalism and consciously suggested his exclusive attention to literature. It is easily detectable that Wilde never posited journalism at the same level as literature or criticism. But as it is shown above, Wilde was, in every sense, a journalist during most of the $1880 \mathrm{~s}$. To this maverick aesthete who tried hard to gain public fame, years of journalistic writing provided him with an opportunity to know the popular taste of his time. Therefore, in Wilde's discussion of contemporary journalism, there was always a kind of paradoxical feeling towards the thing he condemned and the life he pursued.

In "The Soul of Man under Socialism," Wilde said, "In this century journalists have nailed their own ears to the keyhole" [8]. With this metaphorical condemnation of the press's intrusion into the private life, Wilde denounced those journalists for dragging "before the eyes of the public some incident in the private life of a great statesman," and inviting "the public to discuss the incident, to exercise authority in the matter, to give their views, and not merely to give their views, but to carry them into action" [8]. Taking into account of this detailed discussion about journalism, it seems necessary to avoid seeing Wilde's notion of "the survival of the vulgarest" in its relation to journalism simply as the Arnoldian view of offering sensual pleasures to the reading public. Wilde's idea was more complex and speculative than that. His focus was mainly on the contemporary press's transgression of the private and public boundaries. Wilde tended to point out that, by turning readers' attention away from the common political issues onto the private lives of the influential men, the press not only offensively disturbed the personal space but also controlled the public opinion, which could get effect instantly with unreasonable actions. While analyzing the late-Victorian journalism, Jean K. Chalaby interprets this transforming process as "de-politicization". He explains: "A major aspect of the personification of public life by journalists was the disclosure of politicians' private life, a phenomenon which can be traced back to the 1880s in the British press" [14]. Wilde's discussion in "The Soul of Man under Socialism" in 1891 made it clear that the press, as a socially powerful agency, performed a monopolizing force on its readers.

The worry about the fatal effect of publicity caused Wilde to warn that the "private lives of men and women should not be told to the public" [8]. With this remark, Wilde made a comparison between the journalism of England and that of France. He said: "In France, in fact, they limit the journalist, and allow the artist almost perfect freedom. Here we allow absolute freedom to the journalist, and entirely limit the artist"
[8]. These radical words about the different social positions of journalists and artists could be taken as Wilde's open claim for aesthetes of the privilege within the public space and a reaction against the public suppression of artistic freedom. Wilde used the word "most" emphatically to express his utter disgust at those seemingly serious journalists, whose freedom stood in stark contrast to the awkward situation of artists. In "The Critic as Artist," Wilde called those engaged in journalistic writing "our second-rate litte'rateurs", "the mere body-snatchers of literature" [8]. They seized the literary realm from the hands of artists and turned it into a place for exhibition of clumsiness. Finding himself in this predicament, Wilde longed for a "perfect freedom" to create before the vulgar public a world of decent beauty. The term "perfect freedom" seemed to remind the reader that the point was not that the public had no right to know about a person's private life, but that the secret should be delivered to the public through the intervention of artists. Bearing the autonomous aesthetic sphere in mind, Wilde imparted an idea to the world: The aesthetic ideology he celebrated rebelliously with his self-fashioning was a devoted attempt to compete for a place of artistic exhibition within the general vulgarizing process, and for most of the time, it was a determined involvement into this process.

\section{Re-enchantment of "The Sphinx Without a Secret"}

From the observations above, we can see that Wilde's aesthetic principle was always subordinate to a larger argument: the relationship between the private and the public. Wilde never tended to explore the issue deeply or seriously. Instead, he felt quite conformable at the surface level. As S. I. Salamensky argues, Wilde's "artistry and intellectual project were based on playful experimentation with appearances" [15]. By building up an ephemeral public image with bizarre appearances and witty epigrams, Wilde committed himself to an "aesthetics of surface" [16]. The following part attempts to reveal how the aesthetic critical discourse produced a unique exhibition effects by studying Wilde's verbal self-presentation in "The Critic as Artist".

Nearly around the same period as Wilde was working on "The Critic as Artist," Wilde wrote a short story named "The Sphinx without a Secret." On the surface of it, the two works had no relevance with each other. They belonged to different genres and served different purposes: one was a critical article on aesthetic criticism, and the other was a fictional account of love. Nevertheless, a closer reading of the texts exposed that they were devoted to the discussion of the same theme. In the story, by depicting a "Sphinx without a secret," Wilde metaphorically presented the ideas he expressed in "The Critic as Artist": Modern art had been deprived of its enchanted beauty by public vulgarization and thus lost its mystery, so it was the critic's duty to re-enchant the shallow art with exhibition of his own artistic personality and refined taste.

"[H] abitually described as a kind of verbal magician," John 
Stokes records, Wilde "could bring objects to life, a shaman, and several people claimed to have seen a halo around his head" [17]. Such an exaggeration of Wilde's verbal enchantment to his audience draws our attention to the special imagery effect of his witty epigrams. It is usually the case that while reading "The Critic as Artist," the reader is quick in remembering what Wilde says, but it is not easy for him to grasp the definite meaning of Wilde's words. Good examples are to be found everywhere in the essay:

$[\mathrm{T}]$ he primary aim of the critic is to see the object as in itself it really is not. [8]

Where one had fancied that he had something to conceal, they have proved that he had but little to reveal." [8]

When man acts he is a puppet. When he describes he is a poet." [8]

If Hamlet has something of the definiteness of a work of art, he has also all the obscurity that belongs to life. There are as many Hamlets as there are melancholies. [8]

Seen from these sentences, Wilde is deliberate in casually expressing his ideas. Besides, in his arguments, Wilde always favors paradoxes, which seem to come from his strategy of not asking for explicit feedback. That is to say, Wilde's superior ability to seduce readers into attention to what he has said does not lie in the meaningful inspirations contained in the words, as Nicholas Frankel argues: "Within an economy of pleasure, Wilde's text may be the occasion for the work's meaning, but it is not in itself the site of that meaning" [18]. Instead, the main attraction of his words depends on the effect produced by his fecund linguistic outpourings. Kristian Williams has a vivid description of the imploding effect caused by Wilde's paradoxes: "They take the form of bold assertions that deny the obvious or contradict themselves. They offer no counter-truth to the orthodoxy, no new doctrine on which to stand" [19]. Those aphoristic expressions carry with them an imagery peculiarity that constantly refuses to be defined by rigid words, as Wilde professes in De Profundis: "The faith that others give to what is unseen, I give to what one can touch, and look at" [20]. Considering himself "a lord of language" [8], Wilde distinguishes himself from others by providing a special sensation for the pleasure of eyes. This visuality, in return, contributes greatly to the exhibition of the aesthetic image that he desires so intensely.

In "The Critic as Artist" the way Wilde picks up the discussion of Hellenism has nothing to do with a scholarly engagement or a full understanding of his argument on the reader's side. Instead, the whole pleasure of presenting the long lists of Greek names and works in the essay lies in the realization that his learning is "being exhibited for the readers' admiration" [21]. For instance, Wilde writes:

But I see that the moon is hiding behind a sulphur-colored cloud. Out of a tawny mane of drift she gleams like a lion's eye. She is afraid that I will talk to you of Lucian and Longinus, of Quinctilian and Dionysius, of Pliny and Fronto and Pausanias, of all those who in the antique world wrote or lectured upon art matters. [8]

It is easy to detect that the mention of ancient Greek names in the paragraph does not contribute to the argument, but seen from the perspective of "style", which Wilde repeatedly stresses in "The Critic as Artist," they are indispensable. Wilde takes style - the very thing that is associated with individualism as the real essence of literary creation. He remarks: "[T] here is no art where there is no style, and no style where there is no unity, and unity is of the individual," and "Where there is no style a standard must be impossible" [8]. In the essay, Wilde cites examples of both ancient Greek poets and modern novelists to illustrate the importance of style. He argues: "Who indeed but a Greek could have analyzed art so well?... [W]e find the artistic temperaments of the day [such as Aristotle and Plato] investigating every question of style and manner" [8]. Gustave Flaubert "was able to create a classic," because he "[made] a masterpiece of style" [8], while Rudyard Kipling added vulgarity to what he told by the "mere lack of style" [8]. The topic of "style" is also frequently discussed in Wilde's other works. In "The Decay of Lying" Wilde expresses his admiration for style in the following sentences: "[T] he limitation, the very condition of any art is style" [8]. "Truth is entirely and absolutely a matter of style" [8]. "It is style that makes us believe in a thing — nothing but style" [8]. In "Pen, Pencil, and Poison," Wilde takes Thomas Griffiths Wainewright as an excellent art critic because he tries to "revive style as a conscious tradition" [8]. Wilde even makes a startling statement by transforming ethical concern into an exhibition of style in "Preface to The Picture of Dorian Gray": "An ethical sympathy in an artist is an unpardonable mannerism of style" [22]. Wilde's writings display a pervasive fascination with style — the style as "sign of manners," "mode of life," and a kind of aesthetic "attitude". In this sense, Neil Sammells is right in saying that "the dominant aesthetic category for Wilde is not art, but style" [23].

Therefore, style constitutes the most crucial aspect of Wilde's aesthetics of exhibitionism. For Wilde, style is "a series of aesthetic choices governing the ways we see the world, the ways we represent it, and the ways we present ourselves to it" [23]. In the case of the Greek quotations in "The Critic as Artist," we notice that Wilde says of them in a manner as to exhibit his learning and stylistic artistic taste, as Guy and Small argue: "[T]he chief function of these Greek quotations is (again) rhetorical, to show that the speaker... has enjoyed a certain sort of education-that Greek phrases come to him as naturally and frequently as English ones (or indeed French ones)" [21]. These Greek quotations show that Wilde is engaged in the conspicuous exhibition of classical knowledge. By making the Greek forms expressive of themselves, he attempts to work immediately on the senses of the reader. In a review of Pater's Imaginary Portraits published in Pall Mall Gazette in June 1887, Wilde points out that to "convey ideas through the medium of images has always been the aim of those who are artists as well as thinkers in literature, and it is to give a sensuous environment to intellectual concepts that we owe Mr. Pater's last volume" [13]. In Wilde's opinion, Pater "has taken the sensationalism of Greek philosophy and made it a new method of art criticism" [13]. To a certain extent, Wilde's comment on Pater's imagery sensationalism carries his intense desire to try this new 
sensational way of art criticism in his own critical works, and the use of Greek sources in "The Critic as Artist" finally confirms this point.

Meanwhile, the rarefied pleasure that these Greek quotations provide further testifies the appreciator's unique and exclusive artistic taste. Along with his fiery celebration of style, the "artistic temperament" is another integral part of his aesthetics of exhibitionism. Wilde stresses in "The Critic as Artist": "Temperament is the primary requisite for the critic-a temperament exquisitely susceptible to beauty, and to the various impressions that beauty gives us" [8]. It is worth noting that similar terms such as "artistic temperament," "temperament," "aesthetic sense" all reappear in Wilde's critical works. In "The Critic as Artist" Wilde holds that the "appeal of all art is simply to the artistic temperament" [8] and art addresses itself "not to the faculty of recognition nor to the faculty of reason, but to the aesthetic sense alone" [8], for it is only the "artistic temperaments" that can investigate "every question of style and manner" [8]. In "The Decay of Lying," on presenting the idea that life imitates art rather than art imitates life, Wilde argues that the artistic value of natural beauty "depends entirely on the kind of temperament that receives it, so that the return to Nature would come to mean simply the advance to a great personality" [8]. In "Truth of Masks" Wilde offers an explanation for Shakespeare's close attention to the costume in dramatic works. He says: "knowing how the artistic temperament is always fascinated by the beauty of costume, he [Shakespeare] always introduces into his plays masques and dances, purely for the sake of the pleasure which they give the eye [8]. As these examples show, Wilde always relates the perception of beauty to a distinct artistic personality. By reiterating his remarks on the exclusiveness of "artistic temperament," Wilde draws the public attention to the aesthetic critic himself.

In a letter concerning a review of his collection of fairy tales A House of Pomegranates, Wilde makes the point rather clear:

No artist recognizes any standard of beauty but that which is suggested by his own temperament. The artist seeks to realize in a certain material his immaterial idea of beauty, and thus to transform an idea into an ideal. That is the way an artist makes things. The artist has no other object in making things. [24]

Regardless of any external standard, the aesthetic critic made himself the object of artistic attention. In this way, a self-centered exhibition of the artistic sense aroused the public's curiosity about a satirical mimicry of the aesthetes themselves. The most obvious example was the satirical cartoons of George Du Maurier, in which the aesthete was repeatedly positioned as an eccentric admirer of pure art "one who avidly, at times even lasciviously, devotes himself to the appreciation of obscure works of art, to the collection of fine pieces of china, and to the cultivation of himself as artwork" [25]. Du Maurier's caricatures focused mainly on a parodistic depiction of the aesthete's superficial appreciation and embodiment of beauty, which directly influenced Wilde's own configuration of the aesthetic image in the early 1880 s. Wearing long curly hair, dressed in "a velvet coat, knee-breeches, a loose shirt with a turndown collar, and a floating tie of some unusual shade fastened in a La Valliere knot, and carrying in his hand a lily or a sunflower" [26], Wilde was decorating himself into an agent of beauty to manifest his individualistic style as a public aesthete.

In a letter written to Colonel W. F. Morse, who was in charge of the American tours, Wilde described in great detail the costume he needed for the matine'e at Chicago:

They should be beautiful; tight velvet doublet, with large flowered sleeves and little ruffs of cambric coming up from under collar. I send you design and measurements. They should be ready at Chicago on Saturday for matine'es there at any rate the black one. Any good costumier would know what I want... only knee-breeches instead of long hose. Also get me two pair of grey silk stockings to suit grey mouse-colored velvet. The sleeves are to be flowered- if not velvet then plush-stamped with large pattern. They will excite a great sensation. [24]

Wilde's American tours in 1882 were arranged to advertise Gilbert and Sullivan's play Patience. As Norbert Kohl comments: "[F] rom the very start the American public saw the young Wilde in the context predetermined by Patience: he was the ridiculous apostle of a modish cult of beauty" [27]. Seen from the painstaking description of the clothes above and the expectation of exciting "a great sensation" expressed at the end of the letter, there is no doubt that Wilde of this phase enjoyed the role the public assigned to him. Besides, it is worth noting that several of his American lectures written during this period are engaged in the topic of decoration. One of them is named as "House Decoration" in which Wilde remarks: "And what is the meaning of this beautiful decoration which we call art? In the first place, it means value to the workman and it means the pleasure which he must necessarily take in making a beautiful thing" [6]. In another lecture "The English renaissance of Art" Wilde claims likewise: "For what is decoration but the worker's expression of joy in his work? And not joy merely - that is a great thing yet not enough - but that opportunity of expressing his own individuality which, as it is the essence of all life, is the source of all art" [6]. In "Art and the Handicraftsman" Wilde even states: "[A] 11 the arts are fine arts and all the arts decorative arts" [6].

Wilde's fascination with decorative fashion, beyond argument, comes mainly from William Morris. As Norbert Kohl observes, Wilde is capable of changing the meaning of his predecessors "by setting them in new contexts, and frequently-whether explicitly or implicitly - departing altogether from the lines laid down by his predecessors" [27]. In the citations above, we notice that Wilde deliberately beautifies the work of common handicraftsmen by cultivating a notable and joyous feeling in them. Instead of adopting Ruskin's missionary ideas of liberating the poor from heavy work, Wilde engages himself in improving their sensory experiences in work. Such an attitude has its direct connection with the general preference of what should be the meaning of aestheticism among the public. In British Aestheticism and the Urban Working Classes, 1870-1900 Diana Maltz records: "More often than not, missionary aesthetes failed to gain 
popular support and even encountered direct resistance from the urban workers whose lives they sought to enhance: 'Tis all rot and I don't care!'... 'Oh ain't beautiful!'” [28]. On the contrary, the lower-class workers enthusiastically embraced Wilde's performance of languor aestheticism. One unsigned cartoon in the Punch in 1883 was described at the bottom of the picture as: "Our Academy Guide, No. 163 - Private Frith's View - Members of the Salvation Army, led by General Oscar Wilde, joining in a hymn" [28]. In the picture, Wilde stood among many shabby and noisy lower-class people who shouted aloud to "claim public attention on the streets." At the time, the Salvation Army was "almost universally detested among the middle classes for its vulgarity, its appropriation of tunes that were popular among workers" [28], while Wilde, as the "General" of the Salvation Army, was welcomed by these vulgar people. Though they could find no hope of real salvation in Wilde's decadent aestheticism, they indeed temporally released their pain and anger in a carnival atmosphere by caricaturing the aesthete. In the process, the aesthete took on a comical aspect as an aesthetic clown and the caricaturists rejoiced in their ironic imitations.

These interactions between Wilde and the vulgar public and their satirical caricatures are best described in a contemporary article named "The Æthetes: The Story of a Nineteenth-Century Cult" published on Pall Mall Magazine on 5 January 1895. Its author Thomas F. Plowman says:

Mr. Wilde laid himself out to play a certain ro^le, and when he attitudinized he did it sufficiently well to make it pay.... He had to thank others, as well as himself, for much of the success attending his impersonalization of the typical aesthete, and to no one was he more indebted than to the professional humorist, literary, pictorial and dramatic. [29]

In this article, Plowman tries to show that, by reacting against aestheticism, the anti-aesthetic Victorian public indirectly joined the invention of the stereotype of the aesthete and the aesthete himself also showed a strong inclination of absorbing the delineation of his opposites. The key here is not the mass-culture nature of Wilde, but the assumption that Wilde not only knew very well the integrating process but also consciously joined this vulgarization of the aesthetic image. Driven by a strong desire for public exhibition, Wilde gets deeply involved in the public caricaturing of the aesthetes.

In this process, Wilde's "reinvention" of the aesthetic image and his deliberate promotion of "caricature's caricature" provided a valuable cue to understand the real social nature of Wilde's aestheticism. In "The Decay of Lying” Wilde writes:

The only beautiful things, as somebody once said, are the things that do not concern us. As long as a thing is useful or necessary to us, or affects us in any way, either for pain or for pleasure, or appeals strongly to our sympathies, or is a vital part of the environment in which we live, it is outside the proper sphere of art. To art's subject-matter we should be more or less indifferent. We should, at any rate, have no preferences, no prejudices, no partisan feeling of any kind. [8]

This passage is usually taken as Wilde's explicit explanation for "art's for art's sake." At first sight, it resembles in meaning Arnold's account of the disinterestedness of criticism. However, a careful examination exposes fracture rather than consistency in the two arguments. Arnold's disinterested criticism with its mission "to know the best that is known and thought in the world" carries with it a definite moral judgment on what is good and what is bad. Upon this point, Chris Baldick comments: "It is to meet the need for a wider moral authority as a counterpart to the unifying function of the state that Arnold introduces his concepts of 'culture,' 'criticism,' and 'Best Self'" [7]. Contrary to Arnold's moral commitment, Wilde celebrates an aesthetics based on the exhibition of difference and uniqueness. It refuses to accept any judgment within the common perception. In his view, the boundary for artistic criticism does not stand on its own, but exists imaginatively in opposition to the universal recognition of utilitarianism. In his advocacy of the artistic specialty, Wilde knowingly echoes the popular idea about the unorthodox nature of aestheticism, and then remolds it into a more fascinating argument. Quite paradoxically, by displaying a defiant contempt for the ordinary, Wilde seems prepared to conform to the role the public has set for him.

This interaction between the general vulgarization and the Wildean aesthetic image explains why Wilde's pursuit of beauty is always tainted by an appeal to the popular taste and why his epigrammatic dictation in the critical works contains an exhibition of ostentatious aesthetic temperament. This exhibition can not be fulfilled without his playful involvement with the pubic. However, Wilde's complexity just lies in his inconsistencies, as Gilbert in "The Critic as Artist" expresses: "Through constant change, and through constant change alone, he will find his true unity" [8]. Plowman's judgment in 1895 that Wilde should "thank others" might as well contains another meaning: the anti-aestheticism craze also pushed Wilde into constant changes, for during the period between the end of the 1880 s and the early 1890 s, Wilde took great pains in getting rid of those public influences upon him. It is in this sense that critic Lawrence Danson tends to "make 1891 the climate year"'[30] in Wilde's life, the year when Wilde's well-known collection of critical works Intentions and most controversial novel The Picture of Dorian Gray were published in book form. The two books, though written in different genres and devoted to different topics, actually share one same idea: both of them show Wilde's strong inclination to fight against the influences of others, especially that of the vulgar public.

In the book edition of The Picture of Dorian Gray, Wilde revised the original text that appeared in the July 1890 issue of Lippincott's Monthly Magazine and added a preface to defend his aesthetic principle, in which every word was designed to contest those hostile reviews of the novel in newspapers. In the novel, Basil Hallward, the painter that Wilde later claimed to be himself, proclaims: "But the world might guess it, and I will not bare my soul to their shallow prying eyes. My heart shall never be put under their microscope" [22]. After The Picture of Dorian Gray was published, Wilde wrote several letters to the St James's Gazette to reassert the absolute separation between the sphere of art and the sphere of ethics. 
In one of the letters, while objecting to the magazine's poster saying in large letters that "MR OSCAR WILDE'S LATEST ADVERTISEMENT; A BAD CASE" [31], Wilde protested: "I am the one who requires least advertisement" [24]. In another letter, Wilde directly attacked journalism itself: "To say that such a book as mine should be 'chucked into the fire' is silly. That is what one does with newspapers" [24]. In this letter, Wilde further pointed out: "The pour public, hearing from an authority so high as your own, that this is a wicked book that should be coerced and suppressed by a Tory government, will no doubt, rush to it and read it" [24]. This examination of the press's counter-advertisement of the novel and its manipulative power over the reader's mind showed that Wilde is well aware of the real logic of the journalism of his time. Wilde also wrote a letter to criticize the journalist reviewers: "[A]ny critic who admits the reasonableness of such a theory shows at once that he is quite incapable of understanding what literature is, and what are the rights literature possesses" [24].

It might be out of the same desire to defend his position as different from journalistic writers that Wilde added in "The Critic as Artist" for Intentions a passage, saying:

Who shall set limits to him [the artist]? Not the apostles of that new Journalism which is but the old vulgarity "writ large." Not the apostles of that new Puritanism, which is but the whine of the hypocrite, and is both writ and spoken badly. The mere suggestion is ridiculous. Let us leave these wicked people, and proceed to the discussion of the artistic qualifications necessary for the true critic. [8]

As the passage suggests, Wilde is determined to stand on the opposite side of what Arnold calls the "feather-brained" journalism [31]. His utter disgust at journalism is clearly shown in his refusal to offer even a "mere suggestion." Actually, during the period when Intentions appeared, Wilde was, as Danson observes, "just where he seemed to like to be: in trouble" [30]. Apart from those hostile reviews of The Picture of Dorian Gray, journalistic attacks fell on his works "Pen, Pencil and Poison," "The Decay of Lying," and "The Portrait of Mr. W. H.” James McNeill Whistler also would not miss his moment in reviving the old charge of plagiarism. Therefore, Wilde of this period ambitiously committed himself to the building-up of his personal style, which can be seen from his arduous celebration of personality and superior artistic sensibilities in "The Critic as Artist."

All these efforts, as is already shown, were intended for an exhibition of difference and uniqueness. However, the emphasis upon uniqueness and the celebration of difference met the needs of the time. As Guy and Small notice, the Greek quotations in "The Critic as Artist" possess a very different feature from those in Wilde's early essay "The Rise of Historical criticism" [21]. The chief reason for this difference lies in the fact that they are written "for different occasions and audiences" [21]. Unlike "The Critic as Artist," "The Rise of Historical criticism" was written in 1879 for obtaining an Oxford fellowship, in which Greek knowledge was presented in a serious academic manner. Guy and Small's comparison enables us to see that, despite his denunciation of the vulgar nature of journalism, Wilde eventually failed to throw away its influence on him. As is already analyzed, a distinctive feature of the New Journalism was its lightly tone and emphasis on the sensational. Wilde's use of Greek sources in "The Critic as Artist" at the end of his journalist career, in effect, corresponded to this journalistic fashion. In this sense, Paul L. Fortunato is right in saying that "[c] riticism for Wilde is something thoroughly embedded in the fashions and vicissitudes of its changeable journalistic contexts" [16]. Wilde's subtle transformation of classical knowledge into an object of unique exhibition and sensual pleasure also confirms Nicholas Frankel's statement that Wilde is able to turn "the serious pursuit of meaning into an object of pleasure" and adopt "the language of dogmatic truth... only to turn it away from its truth-claims and into an object of spectacle" [18].

As I have briefly mentioned at the beginning of this part, in the late 1880s when Wilde was working on "The Critic as Artist," he also finished a short story titled "The Sphinx without a Secret." In "The Sphinx without a Secret," Lord Murchison, the hero of the story, fell in love with an elegant woman in Paris, Lady Alroy, who had a beauty "molded out of many mysteries." What puzzled Lord Murchison most was that Lady Alroy often appeared alone in Cumnor Street, a slummy street of Paris. Obsessed deeply with this riddle, Murchison tailed after her but each time he failed to find out the truth. Later, Lady Alroy died of congestion of lungs, and the hostess of the house in Cumnor Street told him that Lady Alroy "simply sat in the drawing-room.... reading books, and sometimes had tea" [8]. Lord Murchison could not believe what he heard and became more confused about Lady Alroy's real identity. At last, Lord Murchison's friend explained to him that the lady was merely "a Sphinx without a secret," who was not mysterious at all. Murchison simply responded: "I wonder?" [8]. The story ends abruptly with this short question.

In Wilde's description, Lady Alroy symbolizes a piece of modern work of art. Behind her ornate appearance, there is nothing mysterious. In "The Critic as Artist", there is a paragraph echoing the theme of the story:

The critic will certainly be an interpreter, but he will not treat Art as a riddling Sphinx, whose shallow secret may be guessed and revealed by one whose feet are wounded and who knows not his name. Rather, he will look upon Art as a goddess whose mystery it is his province to intensify, and whose majesty his privilege to make more marvelous in the eyes of men. [8]

This passage might be the best interpretation of the story, or to put it another way, the story most vividly manifests the subtle ideas contained in these words. In "The Critic as Artist," Wilde repeatedly stresses that modern art has been deprived of mystery by public vulgarization, as Wilde writes: "Formerly we used to canonize our heroes. The modern method is to vulgarize them" [8]. He thus deplores: "Nowadays, we have so few mysteries left to us that we cannot afford to part with one of them" [8]. Unlike Arnold's critic who is engaged in disclosing the "shallow secret" of modern art, the aesthetic critic tries to treat the "disenchanted" art as simply a "starting-point for a new creation"; he would not confine 
himself "to discovering the real intention of the artist and accepting that as final" [8]. Instead, he will use his whole life to re-enchant the art and to make it more fantastic for the public-the beholder of the world.

\section{Conclusion}

As shown above, Oscar Wilde succeeded in acquiring a position in the late-Victorian public sphere. He responded to the new cultural market by playing with it in a seemingly flippant and disrespectful manner. He displayed a strong inclination for a sort of public influence based on an exhibition of individual learning, refined taste, unique aesthetic image and intriguing critical discourse. This exhibition always came as a performance of the critic's own personality. In "The Critic as Artist" Wilde argues that the true critic will "realize himself in many forms, and by a thousand different ways, and will ever be curious of new sensations and fresh points of view.... What people call insincerity is simply a method by which we can multiply our personalities" [8]. Critics tend to take the idea presented in these words as evidence of Wilde's decadence, for it echoed the general decadent thoughts in the late nineteenth century. It is reasonably true to say so from the perspective of the historical development of English aestheticism, but what deserves more attention is the concrete contextual conditions of Wilde's decadence. Calloway points out that it is during the period between 1883 and 1889 that Wilde's "simpler aestheticism underwent a see-change into something darker and more 'decadent"'[32]. This period, as I have shown above, also witnessed a Wilde occupied with journalist reviews and editions. Besides, Wilde's use of the Greek sources served to produce an effect rather than convey a definite meaning. Such a desire for public performance drove Wilde into a cult of his own personality. Like an actor on stage he was fascinated by his own ability to decorate language into many-sided forms, and by his skill to constantly make spectacles of himself in public.

\section{References}

[1] Barleben, Dale. "Legal Reforms, the Blackmailer's Charter, and Oscar Wilde's Trials: The Legal Stage of Modernism." Staging the Trials of Modernism: Testimony and the British Modern Literary Consciousness., Toronto: Toronto UP, 2017: 21-50.

[2] Penry, Tara. "Bret Harte's Oscar Wilde Tale" American Literary Realism. 51.1 (2018): 21-35.

[3] Joseph, Abigail. Exquisite Materials: Episodes in the Queer History of Victorian Style. Newark: Delaware UP, 2019: 1-14.

[4] Freeman Nick. "What Kind of Love Came to Professor Guildea? Robert Hichens, Oscar Wilde, and the Queer Ghosts o Hyde Park.” The Modern Language Review. 111.2 (2016): 333-351.

[5] Wilper, James Patrick. "A Tough Act to Follow: Homosexuality in Fiction after Oscar Wilde." Reconsidering the Emergence of the Gay Novel in English and German. West Lafayette: Purdue UP, 2016: 137-152.
[6] Wilde, Oscar. Essays and Lectures. London: Methuen, 1913: 137-186.

[7] Baldick, Chris. The Social Mission of English Criticism 1848-1932. Oxford: Oxford UP, 1983: 25-43.

[8] Wilde, Oscar. Collins Complete Works of Oscar Wilde. Ed. J. B. Foreman. London: Collins, 1986: 215-1095.

[9] Heyck, T. W. The Transformation of Intellectual Life in Victorian England. London: Croom Helm, 1982: 199.

[10] Eagleton, Terry. The Function of Criticism. London: Verso, 2005: 49-50.

[11] Goodbody, John. "The Star: Its Role in the Rise of the New Journalism." Papers for the Millions: The New Journalism in Britain, 1850s to 1914. Ed. Joel H. Wiener. New York: Greenwood, 1988. 143-164.

[12] Cohen, Ed. Talk on the Wilde Side: Toward a Genealogy of a Discourse on Male Sexualities. New York: Routledge, 1993: 131.

[13] Wilde, Oscar. Selected Journalism. Oxford: Oxford UP, 2004: ix- 22.

[14] Chalaby, Jean K. The Invention of Journalism. London: Macmillan, 1998: 76-77.

[15] Salamensky, S. I. "Re-Presenting Oscar Wilde: Wilde's Trials, Gross Indecency, and Documentary Spectacle." Theatre Journal 54.4 (2002): 575-88.

[16] Fortunato, Paul L. "Wildean Philosophy with a Needle and Thread: Consumer Fashion at the Origins of Modernist Aesthetics." College Literature 34.3 (2007): 37-53.

[17] Stokes, John. Oscar Wilde: Myths, Miracles, and Imitations. Cambridge: Cambridge UP, 1996: 23.

[18] Frankel, Nicholas. Oscar Wilde's Decorated Books. Ann Arbor, MI: U of Michigan P, 2000: 83-85.

[19] Williams, Kristian. "The Anarchist Aphorist: Wilde and Gottesman, Paradox and Subversion." Anarchist Studies 18.2 (2010): 101-108.

[20] Wilde, Oscar. The Complete Works of Oscar Wilde. Ed. Bobby Fong, et al. vol. 2. Oxford: Oxford UP, 2000: 165.

[21] Guy, Josephine M. and Ian Small. Studying Oscar Wilde: History, Criticism, and Myth. Greensboro: ELT, 2006: 97-99.

[22] Wilde, Oscar. The Complete Works of Oscar Wilde. Ed. Bobby Fong, et al. vol. 3 Oxford: Oxford UP, 2000: 167-177.

[23] Sammells, Neil. "Oscar Wilde and the Politics of Style." The Cambridge Companion to Twentieth-Century Irish Drama. Ed. Shaun Richards. Cambridge: Cambridge UP, 2004: 109-121.

[24] Wilde, Oscar. The Complete Letters of Oscar Wilde. Ed. Merlin Holland and Rupert Hart-Davis. London: Fourth Estate, 2000: 431-503.

[25] Freedman, Jonathan. Professions of Taste: Henry James, British Aestheticism, and Commodity Culture. Stanford: Stanford UP, 1990: xxi.

[26] Raymond, E. T. Portraits of the Nineties. London: Unwin, 1921: 140 . 
[27] Kohl, Norbert. Oscar Wilde: The Works of a Conformist Rebel. Cambridge: Cambridge UP, 1989: 70-102.

[28] Maltz, Diana. British Aestheticism and the Urban Working Classes, 1870-1900. New York: Macmillan, 2006: 37-209.

[29] Schwandt, Waleska. "Oscar Wilde and the Stereotype of the Aesthete: An Investigation into the Prerequistes of Wilde's Aesthetic Self-Fashioning." The Importance of Reinventing Oscar: Versions of Wilde During the Last 100 Years. Ed. Richard Corballis, Uwe Böker and Julie Hibbard. Amsterdam: Rodopi, 2002: 91-102.
[30] Danson, Lawrence. Wilde's Intentions: The Artist in His Criticism. Oxford: Clarendon, 1999: 2-128.

[31] Arnold, Matthew. "Up to Easter." Nineteenth Century. May 1887: 629-643.

[32] Calloway, Stephen. "Wilde and the Dandyism of the Senses." The Cambridge Companion to Oscar Wilde. Ed. Peter Raby. Cambridge: Cambridge UP, 1997: 34-54. 